\title{
LPSO 相の檠性変形にて形成する变形带の特徽
}

\author{
萩原幸司 ${ }^{* 1}$ ，本浪雅史 ${ }^{* 1}$ ，山崎倫昭 ${ }^{* 2}$ ，岡本拓也 ${ }^{* 1}$ ，伊津野仁史 ${ }^{* 1}$, \\ 多根正和 ${ }^{* 3}$, 中野貴由 ${ }^{* 1}$, 河村能人 ${ }^{* 2}$
}

\section{Characteristics of the deformation bands formed in the LPSO phase}

\author{
Koji HAGIHARA ${ }^{* 1}$, Masahito HONNAMI, Michiaki YAMASAKI, \\ Takuya OKAMOTO, Hitoshi IZUNO, Masakazu TANE, \\ Takayoshi NAKANO, and Yoshihito KAWAMURA \\ *1 Department of Adaptive Machine Systems, Graduate School of Engineering, \\ Osaka University, 2-1, Yamadaoka, Suita, Osaka 565-0871, Japan
}

\begin{abstract}
Formation of curious deformation bands has been reported as one of the deformation mechanisms occurring in a Mg-based long period stacking ordered (LPSO) phase. The origin of the deformation band is still unknown, and the possibility of the deformation kink band and/or the deformation twin has been discussed. To clarify this, the crystallographic nature of deformation bands formed in the LPSO phase was examined by scanning electron microscope-electron backscatter diffraction (SEM-EBSD) pattern analysis. The deformation band in the LPSO phase was found to show three arbitrariness on its crystallographic nature: an ambiguous crystal rotation axis that varied on the [0001] zone axis from band to band; an arbitral crystal rotation angle that was not fixed and showed relatively wide distributions; and a variation in crystal rotation angle depending on the position even within a deformation band boundary itself. These features were coincident with those observed in the deformation bands formed in $\mathrm{Zn}$ polycrystals, suggesting that the formed deformation bands in LPSO phase crystals are mainly deformation kink bands.
\end{abstract}

Keywords : LPSO-phase, Deformation kink, Deformation twin, Zn single crystal, Deformation microstructure

\section{1. 精击}

熊本大 河村教授らにより近年見出された長周期 積層構造相(LPSO 相)を含有する Mg 合金は, 既存の 材料を上回る新規軽量高強度構造材料として, 非常 に注目を浴びている(1). Mg 合金中にて LPSO 相が 優れた強化相として振る舞う要因を明らかにすべく， LPSO 単相結晶を用いこれまで力学特性に関する検 討が行われてきた. この結果, Mg 基 LPSO 相はそ の構造の複雑さにもかかわらず，底面すべりが比較 的容易に活動し，かつその活動が抑制される場合に も特有の「変形帯」が形成することにより, ある程 度の延性を生み出すことが明らかにされた(2)。この LPSO 相中に形成する「変形帯」については，キン ク変形帯である可能性が提案されていたが, 近年, マイクロピラーを用いた力学試験により変形双晶も 生じる可能性があることが指摘されている( ${ }^{(3)}$. 本研 究では一方向性凝固(DS)処理により作製した方位制

\footnotetext{
" 非会員, 大阪大学大学院工学研究科

(T565-0871 大阪府吹田市山田丘 2-1)

${ }^{2}$ 非会員, 熊本大学大学院自然科学研究科

3 非会員, 大阪大学産業科学研究

E-mail: hagihara@ams.eng.osaka-u.ac.jp
}

御 LPSO 結晶の変形挙動, 変形組織を, キンク変形 帯が形成すると過去に報告されている Zn 結晶中の ものと比較することで，両結晶中で見られる変形帯 の結晶学的特徴, 差異について考察を行った.

\section{2. 实方法}

高周波溶解法により作製した $\mathrm{Mg}_{88} \mathrm{Zn}_{6} \mathrm{Y}_{9}$ (at.\%)母 合金を用い, Ar 雾囲気下, 結晶成長速度 $10 \mathrm{~mm} / \mathrm{h}$ に てブリッジマン法による DS 結晶を育成した. 作製し た DS 結晶中, LPSO 相は界面を(0001) とする板状の 結晶粒形態を示し，成長方向に(0001)界面が平行にな るように結晶粒が整列し伸長していた．TEM 観察に より，この as-grown 試料中の LPSO 相は 18R 構造を 有していることを確認した．また同様の手法により， 純度 $99.99 \%$ の $\mathrm{Zn}$ を用い, $\mathrm{Ar}$ 雾囲気下, 結晶成長速 度 $10 \mathrm{~mm} / \mathrm{h}$ の条件下にて $\mathrm{Zn}$ 単結晶を作製した。ささら に mold cast 法を用い, 上述の DS-LPSO 相結晶と類似 の集合組織を有する $\mathrm{Zn}$ 多結晶試料を作製した。これ 
らの各試料から各結晶粒中の底面が荷重軸と平行と なるような角柱圧縮試験片を切り出し, 室温にて圧縮 試験を実施した。この結果導入された変形帯に対し SEM-EBSP 法を用いた結晶方位解析を行い，各結晶 中の変形帯が示す結晶学的特徵について考察した.

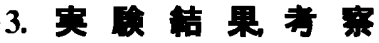

荷重軸肪底面と平行になる方位にて圧縮䚶験を行った ところ，何れの試料中においてもマクロに見ておおよそ 荷重軸に重直な方向に伸びた変形帯の導入が観察された。 ただしその形態は試料により大きく異なり，Zn 単結晶中 では粗大な変形帯が拘束部である試料両端の夕に顕著に 発垟したのに対し， Zn 多結晶詿料およびDS-LPSO 相試 料中では比較的試料全体に微細な変形帯の導入が観察さ れた ただし LPSO 相中では変形帯は多くの場合複数の 変形帯形成浽組となり，図1に示寸ような特有のくちば し状形態を示すのが頻繁に観察されたが，一方Zn多結晶 中では, そのような形態の変形帯はそれほど頻繁には観 察されなか力た。

これら各試料中に導入された変形帯に対し SEM-EBSD 解析を行い，各変形带が示す結晶学的特徴， 具体的には母相中への各変形帯の導入により生じる結晶 回転角の大きさ，またその回転が生じた回転䡛等の評価 を行った.この結果，興味深いことに各試料中に導入さ れた変形帯には以下の様な 3 つの共通点があることが 明らかとなった。

(1) 母相に対する変形帯内の結晶回転軸は，ほと んどが底面と直交する方位であり， $<10 \overline{1} 0>$ 近くの ものが主に観察されるものの， $<11 \overline{2} 0>$ 軸周り，ま た両者から 5 度以上外れるもの等，様々なものが存 在する.

(2) 変形带内の結晶回転角度は，形成初期と思わ れるバンドについても，低角(5 度程度) から 40 度 以上の高角まで，かなり幅広い分布を示す。

(3) 1 つの変形帯界面内においても結晶回転角度 は必ずしも一様でなく，場所に応じて比較的大きな 結晶回転角の分布が存在する.

上記のような特徴は，特定の結晶学的方位関係を 有し形成する変形双晶が示す特徵とは異なっている といえる. すなわち本実験結果は, 形成された変形 帯中に変形双晶が含まれることを否定するものでは ないものの，その多くが「キンク変形帯」と呼ばれ るべきものであることを示唆していると考えられる.

またこの EBSD 解析により, LPSO 相内にて特徴 的に観察される図 1 に示すようなクチバシ状の変形 帯は, 二つ以上の変形帯の合成 (同時形成)により
構成されていること等が明らかとなった. その形成 メカニズムについて今後更に検討を谁める必要があ る.

\section{4. まとめ}

本研究により，Zn 単結晶, 多結晶, ならびにDS-結晶 中で発達する変形帯には，一義的な結晶回転量を持たな い, 回転軸が[0001]軸に直行する任意軸，といった結晶学 的な類以性が認められることが明らかとなり, キンク変 形帯の形成が示唆された. しかし一方で，その分布，サ イズ，形状は各試料中で大きく異なる様相を示すことが 見出され，結晶構造，組織形態の違いが，キンクバンド の形成挙動や付随し発現する力学特性に強、影響を及ぼ す可能性があることが示唆された. 今後この点を更に明 らかにすべく，近年新たに見出された $10 \mathrm{H}$ 型LPSO 相の 塑性挙動等に着目し，さらに検討を進めて行く予定であ る.

\section{文孰}

(1) Y. Kawamura, K. Hayashi, A. Inoue, T. Masumoto, Rapidly solidified powder metallurgy $\mathrm{Mg}_{9} Z_{1} \mathrm{n}_{1} \mathrm{Y}_{2}$ alloys with excellent tensile yield strength above $600 \mathrm{MPa}$, Mater. Trans. Vol.42 (2001), pp.1172-1176.

(2) K. Hagihara, N. Yokotani, Y. Umakoshi, Plastic deformation behavior of $\mathrm{Mg}_{12} \mathrm{YZn}$ with 18R long-period stacking ordered structure, Intermetallics, Vol.18 (2010), pp. 267-276.

（3）井上敦司, 岸田 恭輔, 乾晴行, 萩原幸司, Mg-TM-RE 系 LPSO相単結晶マイクロピラー の圧縮変形, 日本金属学会 2013 秋期大会 講演発表.

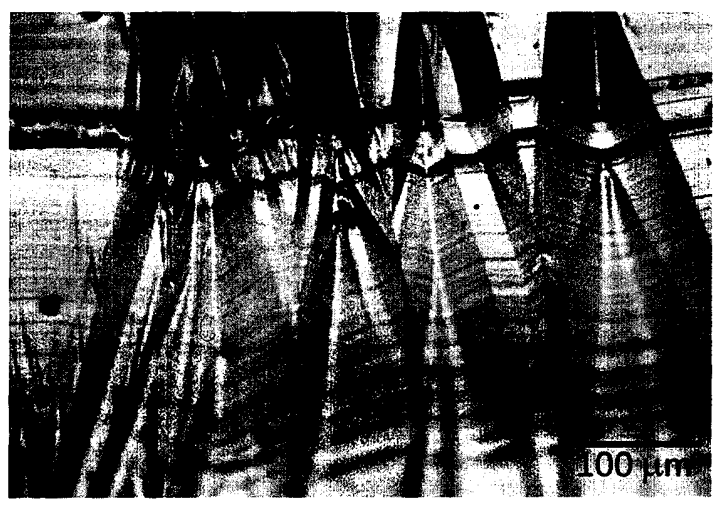

Figure 1 Typical deformation bands formed in the $\mathrm{Mg}_{85} \mathrm{Zn}_{6} \mathrm{Y}_{9}$ LPSO phase DS crystal deformed along the growth direction of the DS crystal at RT. 